\title{
DIRECT AND APPARENT RESIDUAL EFFECTS OF PROHEXADIONE - CALCIUM APPLIED TO YOUNG CROPPING SWEET CHERRY TREES
}

\author{
Tadeusz Jacyna, Tomasz Lipa \\ Department of Pomology, University of Life Sciences, Leszczyńskiego 58, 20-068 Lublin, Poland \\ e-mail: tadeusz.jacyna@up.lublin.pl
}

Received: 20.01.2010

\begin{abstract}
The same young cropping 'Regina' sweet cherry trees were foliar treated with prohexadione-calcium (Pro$\mathrm{Ca})$ in two consecutive years at a concentration of [ 125 , $125 \times 2,250$ ]-(A) and [ 250, 375, 500 ]-(B) $\mathrm{mg} \mathrm{ProCa}^{-1}$, respectively. The following year some trees from A-treatments were left untreated to observe carry-over effects (C). None of A-treatments influenced tree trunk, shoot extension and internode growth, whereas B-treatments reduced shoot extension and internode length, simultaneously increasing flower bud density, particularly by 500 $\mathrm{mg}$ ProCa $1^{-1}$. There were no carry-over effects produced by $\mathrm{C}$-trees, except some retardation in shoot extension. None of the treatments influenced the tree cropping level. Fruit diameter was reduced by A-treatments, but fruit shape (L/D ratio) and mass were reduced by treatments $\mathrm{B}$, and such reduction was also exhibited by C-trees (residual effects).
\end{abstract}

Key words: bioregulators, fruit quality, growth retardation, prohexadione-calcium, Regalis ${ }^{\circledR}$, sweet cherry.

\section{INTRODUCTION}

Most of existing and newly planted sweet cherry orchards in Poland still use trees on vigorous rootstocks. For various reasons, the application of dwarfing rootstocks nowadays is somewhat limited. One of the possibilities to solve the tree growth problem in dense plantings is the application of either special training methods (S it a rek, 2004) or growth controlling substances (Elfving et al. 2003), or both techniques (J a c yna and B uczek, 2008). A plant bioregulator prohexadione-calcium (Regalis ${ }^{\circledR}$, BASF, Germany) offers an effective growth control in pome and stone fruits ( $\mathrm{Basak}$ and $\mathrm{Rademacher}$, $2000)$. The principal mode of action of prohexadione-Ca (ProCa) in reducing shoot elongation in fruit trees results from inhibition of biosynthesis of active gibberellic acid isomers in plant tissues ( $\mathrm{B} \mathrm{a} \mathrm{s} \mathrm{a} \mathrm{k}$ and $\mathrm{R}$ a d e $\mathrm{m}$ a c h e r, 2000). Considering the effectiveness of ProCa in controlling growth of pome fruits, it was supposed that ProCa might facilitate growth control in sweet cherry plantings as well $(\mathrm{Guak}$ et al. 2005; Manriquez et al. 2005; Elfving and Lang, 2005; Anonymous, 2009). Research on ProCa use in sweet cherries, however, is far less advanced than in apples.

The research reported here was designed to evaluate the effects of application of ProCa on tree performance and to observe possible carry-over effects of the compound in young cropping sweet cherries of $\mathrm{cv}$. 'Regina' planted in mid-dense orchards.

\section{MATERIALS AND METHODS}

The experiment was performed in the Hop Experimental Station in Jastków in Lublin province (eastcentral Poland) in the period from 2000 to 2002 (evaluation of carry-over effects). The sweet cherry trees of cv. 'Regina' on Prunus avium L. rootstock were six-year old at the time when the experiment started. The trees were planted at a density of 670 trees ha $^{-1}$ and trained as a semi-spindle canopy. The orchard floor consisted of $100 \mathrm{~cm}$-wide herbicide strips with mowed grass alleyways between. The orchard was protected from birds by special netting.

Treatments: the trees were treated with foliar sprays of Regalis ${ }^{\circledR}$ containing an active ingredient (ai.) prohexadione-calcium (ProCa). No spray additives were applied for work solutions and $\mathrm{pH}$ of water used 
was approximately $5.8-6.0$. The trees were sprayed when the new growth reached about $5-10 \mathrm{~cm}$. The second spray, when applicable, was performed 3 weeks after the first spray (2000). The following year (2001) the experiment was split into two parts, with the first part treated again with ProCa at different rates (see Table 1) but at the same time as in the previous year, and the second part remained untreated to observe possible carry-over effects. The details of the treatments are explained in Table 1.

Table 1

Spray treatments applied to sweet cherry trees of cv. 'Regina'.

All sprays diluted in aqueous solution and sprayed with a hand-wand sprayer to run-off

\begin{tabular}{ccc}
\hline \multicolumn{4}{c}{ Treatments applied $\left(\mathrm{mg} \mathrm{ai} ~^{-1}\right)^{\mathrm{a}}$ in: } \\
\hline 2000 & $2001^{\mathrm{c}}$ & $\mathrm{C}$ \\
\hline $\mathrm{A}^{\mathrm{b}}$ & $\mathrm{B}$ & 0 \\
\hline 0 & 0 & 0 \\
125 & 250 & 0 \\
$125 \times 2$ & 375 & 0 \\
\hline
\end{tabular}

${ }^{\text {a }}$ active ingredient (ai) prohexadione $-\mathrm{Ca}(\mathrm{ProCa})$

${ }^{\mathrm{b}}$ six single-tree replications per each treatment

${ }^{c}$ in 2001 the 2000 treatments were split into two groups, B and C, of three single-tree replications each

Data recording and analysis: a completely randomized design with six single-tree replications was used. The subsequent year six single-tree replications were divided into two equal parts of three single-tree replications to set up two follow-up trials. After each growing season (early spring), the following measurements were performed on every tree: the trunk diameter measured in two directions at $15 \mathrm{~cm}$ above the bud union (the mean trunk diameter was then used for calculation). Two uniform branches located $\approx 2 \mathrm{~m}$ above the soil line positioned in opposite directions were selected for measurements of: branch diameter (measured at its basal portion), periodical recording of elongation of terminal shoots, number and length of lateral shoots (previous-year shoots), internode length (a sample of 30 shoots taken from a different part of each tree canopy was used), and number of flower buds (clusters) on spurs and previous-year shoots. These data were used for various calculations. These branches were used to assess flowering advancement in \% [0\% - no bloom (balloon stage); $\approx 80 \%$ flowers open (full bloom)] and to take samples of fruit for quality estimation. Every year fruit yield was taken from each tree.

The data were subjected to analysis of variance, and for mean separation Tukey's HSD test at $a=0.05$ was used.

\section{RESULTS}

Effect on vegetative growth characteristics: in both years no significant influence of the application of prohexadione-calcium on trunk growth was found; consequently, no residual effect of ProCa was evident (Table 2). Also, no significant changes in internode length were detected when ProCa was applied in 2000. However, the following year (2001) ProCa application $500 \mathrm{mg} \mathrm{l}^{-1}$ significantly reduced internode length as compared with the control, but not otherwise. No residual effect of 2000-ProCa application on internode length was observed (Table 2). Periodical measurements of branch terminal shoots in the active period of growth performed in 2000 did not exhibit any growth retardation except some caused by $250 \mathrm{mg}$ ProCa $\mathrm{I}^{-1}$ that occurred only in the first month after spraying (data not shown). The final measurement of branch terminal shoot revealed no difference between the treatments (Table 3). Despite the lack of data on 2001branch terminal growth, significant differences were found in branch total growth per branch unit (BTEG) and BTEG calculated per $\mathrm{cm}^{2}$ of branch cross-sectional area (BCSA) between treated and control trees. This was clearly shown by the effects of the rate of $500 \mathrm{mg}$ ProCa ${ }^{-1}$ (Table 3). The residual effect of 2000-ProCa application was well expressed by the ratio of BTEG/ $\mathrm{cm}^{2}$ BCSA, where all chemical treatments significantly suppressed shoot extension growth in comparison with the controls. ProCa application did not influence the number of lateral shoots (Table 3 ).

Effect on flower bud formation and cropping: the reapplication rates in 2001 stimulated some increase in flower bud formation. However, the only significant increment in this feature was brought about 
by $500 \mathrm{mg} \mathrm{ProCa}^{-1} \mathrm{vs}$. control. No residual effect of 2000-ProCa rates was observed (Table 4). There was no significant impact of prohexadione-calcium on time of tree blooming. There was some carry-over effect in blooming but it seems to be rather incidental (Table 4). Fruit yields were not affected by ProCa at any occasions, and consequently no carry-over effects were produced (Table 4).

Table 2

Effect of prohexadione-Ca application on tree trunk growth and internode length of 'Regina' sweet cherry trees

\begin{tabular}{|c|c|c|c|c|c|c|c|c|}
\hline \multicolumn{3}{|c|}{ Treatments (mg ProCa $1^{-1}$ ) } & \multirow{2}{*}{\multicolumn{3}{|c|}{$\begin{array}{l}\text { Annual increment of trunk } \\
- \text { cross sectional area }\left(\mathrm{cm}_{\iota}\right)\end{array}$}} & \multirow{2}{*}{\multicolumn{3}{|c|}{ Internode length (mm) }} \\
\hline 2000 & \multicolumn{2}{|c|}{2001} & & & & & & \\
\hline A & $\mathrm{B}$ & $\mathrm{C}$ & A & $\mathrm{B}$ & $\mathrm{C}$ & A & B & $\mathrm{C}$ \\
\hline 0 & 0 & 0 & $24.7 \mathrm{a}$ & $35.6 \mathrm{a}$ & $35.6 \mathrm{a}$ & 36 a & $25 \mathrm{~b}$ & $25 \mathrm{a}$ \\
\hline 125 & 250 & 0 & $22.2 \mathrm{a}$ & $29.8 \mathrm{a}$ & $39.9 \mathrm{a}$ & $35 \mathrm{a}$ & $21 \mathrm{ab}$ & $24 \mathrm{a}$ \\
\hline $125 \times 2$ & 375 & 0 & $22.2 \mathrm{a}$ & $36.5 \mathrm{a}$ & $34.9 \mathrm{a}$ & $37 \mathrm{a}$ & $23 \mathrm{ab}$ & $21 \mathrm{a}$ \\
\hline 250 & 500 & 0 & $18.7 \mathrm{a}$ & $43.5 \mathrm{a}$ & $39.7 \mathrm{a}$ & $35 \mathrm{a}$ & $17 \mathrm{a}$ & $24 \mathrm{a}$ \\
\hline
\end{tabular}

Mean separation by Tukey HSD test at $\mathrm{P}<0.05$. Means followed by the same letter are not significantly different.

Table 3

Effect of prohexadione-Ca application on shoot length, number of shoots and branch extension growth of 'Regina' sweet cherry trees

\begin{tabular}{|c|c|c|c|c|c|c|c|c|c|}
\hline \multicolumn{3}{|c|}{ Treatments (mg ProCa $\left.~^{-1}\right)$} & \multirow{3}{*}{$\begin{array}{c}\begin{array}{c}\text { Length of branch } \\
\text { terminal shoot } \\
(\mathrm{cm})\end{array} \\
\mathrm{A}\end{array}$} & \multirow{2}{*}{\multicolumn{2}{|c|}{$\begin{array}{l}\text { Number of lateral } \\
\text { shoots per branch }\end{array}$}} & \multirow{2}{*}{\multicolumn{2}{|c|}{$\begin{array}{l}\text { Branch total extension } \\
\text { growth (BTEG) } \\
(\mathrm{cm})\end{array}$}} & \multirow{2}{*}{\multicolumn{2}{|c|}{$\begin{array}{l}\text { Branch total extension } \\
\text { growth (BTEG) per } \\
\mathrm{cm}_{\mathrm{c}} \text { of BCSA }{ }^{\mathrm{a}}\end{array}$}} \\
\hline 2000 & \multicolumn{2}{|c|}{2001} & & & & & & & \\
\hline A & $\mathrm{B}$ & $\mathrm{C}$ & & $\mathrm{B}$ & $\mathrm{C}$ & $\mathrm{B}$ & $\mathrm{C}$ & B & $\mathrm{C}$ \\
\hline 0 & 0 & 0 & $41.5 \mathrm{a}$ & $6.3 \mathrm{a}$ & $6.3 \mathrm{a}$ & $87.8 \mathrm{~b}$ & $87.8 \mathrm{~b}$ & $14.0 \mathrm{~b}$ & $14.0 \mathrm{~b}$ \\
\hline 125 & 250 & 0 & $37.2 \mathrm{a}$ & $6.1 \mathrm{a}$ & $7.3 \mathrm{a}$ & $56.7 \mathrm{ab}$ & $55.8 \mathrm{ab}$ & $6.2 \mathrm{a}$ & $6.4 \mathrm{a}$ \\
\hline $125 \times 2$ & 375 & 0 & $43.0 \mathrm{a}$ & $6.0 \mathrm{a}$ & $4.8 \mathrm{a}$ & $64.3 \mathrm{ab}$ & $50.8 \mathrm{a}$ & $8.9 \mathrm{ab}$ & $5.9 \mathrm{a}$ \\
\hline 250 & 500 & 0 & $39.8 \mathrm{a}$ & $5.1 \mathrm{a}$ & $6.6 \mathrm{a}$ & $46.7 \mathrm{a}$ & $64.0 \mathrm{ab}$ & $6.5 \mathrm{a}$ & $8.4 \mathrm{a}$ \\
\hline
\end{tabular}

Mean separation by Tukey HSD test at $\mathrm{P}<0.05$. Means followed by the same letter are not significantly different. ${ }^{\text {a }}$ branch crosssectional area.

Table 4

Effect of prohexadione-Ca application on flower bud formation, number of flowers open at full bloom, and cropping of 'Regina' sweet cherry trees

\begin{tabular}{|c|c|c|c|c|c|c|c|c|c|}
\hline \multicolumn{3}{|c|}{ Treatments (mg ProCa $\left.~^{-1}\right)$} & \multirow{2}{*}{\multicolumn{2}{|c|}{$\begin{array}{l}\text { Number of flower } \\
\text { clusters per } \mathrm{cm} \text { of } \\
\text { branch length }\end{array}$}} & \multirow{2}{*}{\multicolumn{2}{|c|}{$\begin{array}{l}\% \text { of flowers open } \\
\text { at full bloom } \\
\text { at the fixed date }\end{array}$}} & \multirow{2}{*}{\multicolumn{3}{|c|}{$\begin{array}{c}\text { Fruit yield } \\
\text { (kg/tree) }\end{array}$}} \\
\hline 2000 & \multicolumn{2}{|c|}{2001} & & & & & & & \\
\hline $\mathrm{A}$ & B & $\mathrm{C}$ & B & $\mathrm{C}$ & B & $\mathrm{C}$ & A & B & $\mathrm{C}$ \\
\hline 0 & 0 & 0 & $0.91 \mathrm{a}$ & $0.91 \mathrm{a}$ & $43 \mathrm{a}$ & $43 \mathrm{a}$ & $5.5 \mathrm{a}$ & $4.5 \mathrm{a}$ & $4.5 \mathrm{a}$ \\
\hline 125 & 250 & 0 & $1.08 \mathrm{ab}$ & $1.51 \mathrm{a}$ & $57 \mathrm{a}$ & $62 \mathrm{~b}$ & $6.2 \mathrm{a}$ & $2.1 \mathrm{a}$ & $3.0 \mathrm{a}$ \\
\hline $125 \times 2$ & 375 & 0 & $1.01 \mathrm{ab}$ & $1.81 \mathrm{a}$ & $50 \mathrm{a}$ & $48 \mathrm{ab}$ & $5.9 \mathrm{a}$ & $3.6 \mathrm{a}$ & $3.0 \mathrm{a}$ \\
\hline 250 & 500 & 0 & $2.33 \mathrm{~b}$ & $1.09 \mathrm{a}$ & $47 \mathrm{a}$ & $47 \mathrm{ab}$ & $5.1 \mathrm{a}$ & $2.2 \mathrm{a}$ & $5.3 \mathrm{a}$ \\
\hline
\end{tabular}

${ }^{\mathrm{a}}$ on May 2, 2001.

Mean separation by Tukey HSD test at $\mathrm{P}<0.05$. Means followed by the same letter are not significantly different. 
Effect on some characteristics of fruit quality: fruits harvested from 2000-ProCa treated trees tended to have a greater diameter than those from the control trees, and this response appeared to be ratedependent (Table 5). A similar response to chemical treatment was expressed by the ratio of L/D. Fruits from the trees treated at $500 \mathrm{mg}$ ProCa $~^{-1}$ were significantly more flattened than fruits from the remaining treatments. Thus, it may indicate that fruits from 500 mg ProCa $l^{-1}$ treated trees had a greater diameter than those from other treatments. Generally, in both reapplication (B) and no-application (C) treatments fruit volume and mass tended to diminish when ProCa concentration increased. However, these trends were not fully statistically proven (Table 5).

Table 5

Effect of prohexadione-Ca application on diameter, volume and shape of fruits of 'Regina' sweet cherry trees

\begin{tabular}{|c|c|c|c|c|c|c|c|c|c|c|}
\hline \multicolumn{3}{|c|}{ Treatments (mg ProCa $~^{-1}$ ) } & \multirow{3}{*}{$\begin{array}{c}\begin{array}{c}\text { Fruit } \\
\text { diameter } \\
(\mathrm{mm})^{\mathrm{a}}\end{array} \\
\mathrm{A}\end{array}$} & \multirow{2}{*}{\multicolumn{2}{|c|}{$\begin{array}{l}\text { Fruit shape } \\
{(\mathrm{L} / \mathrm{D} \text { ratio })^{\mathrm{c}}}^{\mathrm{c}}\end{array}$}} & \multirow{2}{*}{\multicolumn{2}{|c|}{$\begin{array}{l}\text { Volume of } 100 \text { fruits } \\
\qquad(\mathrm{cml})^{\mathrm{b}}\end{array}$}} & \multirow{2}{*}{\multicolumn{3}{|c|}{$\begin{array}{l}\text { Mass of } 100 \text { fruits } \\
(\mathrm{g})\end{array}$}} \\
\hline 2000 & \multicolumn{2}{|c|}{2001} & & & & & & & & \\
\hline A & $\mathrm{B}$ & $\mathrm{C}$ & & $\mathrm{B}$ & $\mathrm{C}$ & B & $\mathrm{C}$ & A & $\mathrm{B}$ & $\mathrm{C}$ \\
\hline 0 & 0 & 0 & $23.5 \mathrm{a}$ & $1.06 \mathrm{~b}$ & $1.06 \mathrm{~b}$ & $962 \mathrm{a}$ & $962 \mathrm{a}$ & $847 \mathrm{a}$ & $983 \mathrm{ab}$ & $983 \mathrm{~b}$ \\
\hline 125 & 250 & 0 & $23.7 \mathrm{ab}$ & $1.06 \mathrm{~b}$ & $1.06 \mathrm{~b}$ & $970 \mathrm{a}$ & $917 \mathrm{a}$ & 857 a & $999 \mathrm{ab}$ & $941 \mathrm{a}$ \\
\hline $125 \times 2$ & 375 & 0 & $24.0 \mathrm{~b}$ & $1.05 \mathrm{~b}$ & $1.04 \mathrm{a}$ & $972 \mathrm{a}$ & $907 \mathrm{a}$ & $878 \mathrm{a}$ & $1016 \mathrm{~b}$ & $958 \mathrm{a}$ \\
\hline 250 & 500 & 0 & $24.1 \mathrm{~b}$ & $1.03 \mathrm{a}$ & $1.05 \mathrm{~b}$ & $913 \mathrm{a}$ & $900 \mathrm{a}$ & $879 \mathrm{a}$ & $947 \mathrm{a}$ & $951 \mathrm{a}$ \\
\hline
\end{tabular}

${ }^{\text {a }}$ measured in both directions using 25 fruits per replicate

b measured according to Archimedes' law using 100 fruits immersed in 1 liter of water.

${ }^{\mathrm{c}}$ length/diameter ratio

Mean separation by Tukey HSD test at $\mathrm{P}<0.05$. Means followed by the same letter are not significantly different.

\section{DISCUSSION}

Prohexadione-calcium (ProCa) is known for its growth retardation in pome fruits ( $\mathrm{Evans}$ et al. 1997; Unrath, 1999; B as ak and Rade ma$\mathrm{ch}$ e r, 2000). Yet, not much information is available for stone fruits, and particularly for sweet cherry trees (Byers and Yoder, 1999; Elfving et al. 2003; Guak et al. 2005).

Our first approach to control vegetative growth of vigorous 'Regina' sweet cherry trees by means of prohexadione-calcium has failed to succeed. It is believed that several factors, such as the number of chemical applications (B a sak and Rade macher, 2000; Rademacher and Kober, 2003; Elfving and Lang, 2005; Prive et al. 2006), chemical concentration (Byers and Yoder, 1999; Rademacher and Kober, 2003; Guak et al., 2005; Manriquez et al. 2005; Anonymou s, 2009), time of application (B a sak and $\mathrm{Ra}$ demacher, 2000; Greene, 1999; Guak et al. 2005), cultivar ( Greene, 1999; Villardel et al. 2000; Elfving et al. 2003; B asak, 2004; Anonymous, 2009), and/or quality of water used for spraying ( $\mathrm{R} \mathrm{ade} \mathrm{mach}$ e $\mathrm{r}$ and $\mathrm{Ko}$ ber, 2003; Schupp et al. 2003; Cline et al. 2008), may be of paramount importance to control tree performance by this compound.
Comparison of our results (2000) with those of Elfving et al. (2003), Guak et al. (2005), Manriquez et al. (2005) and Anonymous (2009) may suggest that the most likely factors responsible for low efficiency of ProCa in growth retardation might have been either the genetic make-up of cv. 'Regina' or ProCa concentration, or the interaction of both factors. Elfving et al. (2003) reported that, in contrast with such ProCa responsive cultivars as 'Bing', 'Kordia' and 'Lapins', no growth inhibition in 'Regina' trees occurred when treated at 125 or 250 mg ai $1^{-1}$. These results confirmed our unpublished results (2000), despite some differences in time of chemical application between both trials.

Increasing ProCa concentration over $250 \mathrm{mg}$ ai $\mathrm{I}^{-1}$ did not cause any significant improvements in retardation, except the rate of $500 \mathrm{mg}$ ai $\mathrm{l}^{-1}$ which reduced internode length and to some extent shoot extension. ProCa did not stimulate the increase of shoot number in 'Regina' and other sweet cherry cultivars. This confirms the results published by Elfving et al. (2003) as well as Elfving and Lang (2005) and contradicts those by B a s ak (2007) relating to 'Jonagold' apple trees.

The solubility of ProCa in water is low, being closely linked to water $\mathrm{pH}$ that influences its efficiency (Rademacher and Kober, 2003). Therefore, the increase of ProCa rates does not always bring 
expected results. Byers and Yoder (1999), Greene (1999) and Prive et al. (2006), however, reported that higher concentrations of ProCa improved its efficiency in growth retardation of apples. No such data have been presented for sweet cherries so far. Then, it is likely that to suppress vegetative growth of 'Regina' trees higher concentrations of ProCa are needed than those usually applied to apple trees. The data on shoot extension growth taken two years after ProCa application indicated some carry-over effects. The reason for this phenomenon is not clear, however, this was evident for all chemical treatments $v s$. control trees. We suppose then that the unsatisfactory performance of ProCa in suppressing vegetative growth of 'Regina' trees was predominantly associated with the cultivar per se. Also, the quality of water used for spraying may not be overlooked. Elfving et al. (2003) found no reduction in shoot growth when 'Regina' trees were treated at $250 \mathrm{mg}$ ProCa $1^{-1}$ dissolved in water of $\mathrm{pH}$ about 5 . We used unbuffered tap water of $\mathrm{pH}$ about 6. Comparing Elfving's and our results, we concluded that 'Regina' trees ought to be treated with rates higher than $250 \mathrm{mg}$ ProCa $\mathrm{l}^{-1}$ using more acidified water solution (Wielgus, 2008). Rade$\mathrm{macher}$ and Kober (2003) reported that ProCa is readily absorbed by plant tissue in non-dissociated form in aqueous solution at $\mathrm{pH}<5$. Therefore, through water acidification, an increase of chemical uptake, better efficiency of ProCa in difficult-to-retard sweet cherry cultivars may be expected.

ProCa on its own neither stimulates bloom return nor yields an increase in sweet cherry trees (E 1 fving et al. 2003; 2004), Elfving and Lang (2005), Guak et al. (2005). The only rate of Pro$\mathrm{Ca}$ that contributed to an increase of flower bud density

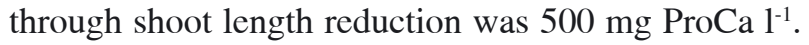
This effect of ProCa may be improved if ProCa will be combined with ethephon (Elfving et al. 2003; 2004; Elfving and Lang, 2005; Wielgus, 2008 ). In spite of some increase in flower bud formation, no difference in cropping level was noted. This is in agreement with the results obtained from different experiments on sweet cherries and other fruit species (B asak, 2004; Elfving and Lang, 2005; Guak et al. 2005; Cline et al. 2008). Pro$\mathrm{Ca}$ has low potential to increase fruit yields calculated on a tree basis (Greene, 1999; Schupp et al. 2003; Elfving et al. 2003; 2004; B asak, 2004; 2007; Cline et al. 2008). Not much data are available on the relation of ProCa treatment vs. sweet cherry fruit quality. It is known that ProCa hardly affects apple firmness, content of soluble solids, size and mass of fruit (B y e r s and Y oder, 1999; Greene, 1999; Basak, 2004; 2007; Cline et al. 2008). It appears that these fruit quality characteristics for sweet cherries $(\mathrm{Guak}$ et al. 2005; G ło s and Krawczyk - unpublished) follow the quality pattern for apples treated by prohexadione-calcium.

\section{CONCLUSIONS}

The results of these studies demonstrated that prohexadione-Ca may be a valuable tool, controlling vegetative growth, in orchard technology of young, vigorous cropping 'Regina' sweet cherry trees. The application of this compound at the rate above 250 up to $500 \mathrm{mg} \mathrm{l}^{-1}$ is able to establish acceptable growth control without negative effects on bloom return, fruit yield and fruit quality. In spite of its low ability to increase tree fruit yields, an increment in orchard production efficiency is realistic. It may be accomplished by a significant reduction of tree size, thus increasing the number of trees per unit area, and consequently fruit yields.

This research suggests that due to the commercial importance of cv. 'Regina' in the Polish cherry industry, further studies should be undertaken to include rates, frequency of application and levels of acidification of water carrier.

\section{Acknowledgements}

The authors are grateful to graduate students Mirosław Skałecki and Konrad Głos of the University of Life Sciences in Lublin for their assistance in data collection.

\section{REFERENCES}

A nony mous, 2009: Application of prohexadione-Ca in sweet cherry plantings., [In:] http//ucr.altavoz.net/prontusunidcad/site/artic/20061211/asocfile/2006121142255/ aliaga_oscar.pdf

B a s a k A., 2004: Growth and fruiting of 'Elstar' apple trees in response to prohexadione calcium depending on the rootstock. Acta Hort. 653: 117-125.

B a sak A., 2007: The effect of prohexadione-Ca on shoot growth and cropping of young apple trees of cv. 'Jonagold'. Rocz. A.R. Pozn. Vol. CCCLXXXIII. Ogrodn. 41: 261-268.

Basak A., Rademacher W., 2000: Growth regulation of pome and stone fruit trees by use of prohexadione-calcium. Acta Hort. 514: 41-50.

Byers R.E., Yoder K.S., 1999: Prohexadione-calcium inhibits apple but not peach, tree growth, but has little influence on apple fruit thinning and quality. HortScience, 34 (7) : 1205-1209.

Cline J.A., Embree C.G., Hebb J., Nichols D.S., 2008: Performance of prohexadione-calcium on shoot growth and fruit quality of apple - effect of spray surfactants. Can. J. Plant Sci. 88: 165-174. 
Elfving D.C., Lang G.A., 2005: Effects of prohexadione-calcium and ethephon on growth and flowering of'Bing' sweet cherry. Acta Hort. 667:439-446.

Elfving D.C., Lang G.A., Visser D.B., 2003: Prohexadione- $\mathrm{Ca}$ and ethephon reduce shoot growth and increase flowering in young vigorous sweet cherry trees. HortScience, 38 (2): 293-298.

Elfving D.C., Visser D.B., Whiting M.D., 2004: Growth and flowering resoponses of sweet cherry cultivars to prohexadione-calcium and ethephon. Acta Hort. 636: 75-81.

Evans R.R., Evans J.R., Rademacher W., 1997: Prohexadione-calcium for suppression of vegetative growth in eastern apples. Acta Hort. 451: 663-666.

Greene D.W., 1999: Tree growth management and fruit quality of apple trees treated with prohexadione-calcium (BAS 125). HortScience, 34 (7): 1209-1212.

Guak S., Beulak M., Looney N.E., 2005: Controlling growth of sweet cherry trees with prohexadionecalcium: Its effect on cropping and fruit quality. Acta Hort. 667: 433-437.

Jacyna T., Buczek, M., 2008: Use of bioregulators to hasten sweet cherry canopy development. Acta Hort., 795: 509-512.

Manriquez D., Defilippi B., Retamales J., 2005: Prohexadione-calcium, a gibberellin biosynthesis inhibitor can reduce vegetative growth in 'Bing' sweet cherries. Acta Hort. 667: 447-451.

Prive J.P., Cline J., Fava E., 2006: Influence of prohexadione-calcium (Apogee ${ }^{\circledR}$ ) on shoot growth of non-bearing mature apple trees in two different growing regions. Can. J. Plant Sci. 86: 227-233.

Rademacher W., Kober R., 2003: Efficient use of prohexadione$\mathrm{Ca}$ in pome fruits. European J. Hort. Sci. 68 (3): 101107.

Schupp J.R., Robinson T.L., Cowgill P.J.Jr., Compton J.R., 2003: Effect of water conditioners and surfactants on vegetative growth control and fruit cracking of 'Empire' apple caused by prohexadionecalcium. HortScience, 38 (6): 1205-1209.

Sit a rek M., 2004: Uprawa czereśni karłowych / Cultivation of dwarf sweet cherries, ed. Plantpress, Kraków: 190 (in Polish).
Unrath C.R., 1999: Prohexadione-Ca: a promising chemical for controlling vegetative growth of apples. HortScience, 34 (7): 1197-1200.

Villardel P., Carbo J., Bonany J., Guanter G., 2000: Foliar application of prohexadione-Ca for reducing vegetative growth af apple and pear trees. Journales de Experimentacion en Frutticultura, 21: 217-223 (abstract).

Wi elg u s, M., 2008: Vegetative growth and its inhibition in young cropping sweet cherry trees: Growth inhibition by prohexadione-Ca and ethephon. MS Thesis, University of Life Sciences in Lublin, Poland.

\section{Działanie bezpośrednie i następcze proheksadionu wapnia (Regalis ${ }^{\circledR}$ ) zastosowanego na młode owocujące drzewa czereśni}

\section{Streszczenie}

6-letnie drzewa czereśni odmiany 'Regina' na podkładce czereśni ptasiej opryskiwano w dwóch kolejnych latach preparatem Regalis ${ }^{\circledR}$ zawierającym proheksadion wapnia (ProCa), odpowiednio w dawkach [125, $125 \times$ 2, 250]-(A) i [250, 375, 500]-(B) mg ProCa l-1 dla I i II roku stosowania. Część drzew z kombinacji A pozostawiono bez opryskiwania w celu obserwacji następczego działania ProCa (C). Żadna z kombinacji A nie ograniczyła wzrostu pnia, pędów i długości międzywęźli. Kombinacje B istotnie zredukowały sumę długości pędów i długości międzywęźli oraz przyczyniły się do zwiększenia liczby pąków kwiatowych. Najskuteczniejszą pod tym względem okazała się dawka $500 \mathrm{mg}$ ProCal $^{-1}$.Niestwierdzononastępczegowpływukombinacji A (drzewa $\mathrm{C}$ ) na badane cechy drzewa $\mathrm{z}$ wyjątkiem redukcji sumy długości pędów. Żadna z kombinacji nie wpłynęła na plon owoców. Kombinacje A redukowały średnicę owoców, zaś kombinacje B i nie traktowana kombinacja A (drzewa C) wpłynęły na zmniejszenie masy owoców i ich kształt (L/D). 